\title{
HOMOLOGOUS TISSUE SENSITIZATION FAILURE TO PRODUCE JOINT AND KIDNEY LESIONS OR PRECIPITINS WITH HOMOLOGOUS TISSUES PLUS STREPTOCOCCI*
}

\author{
BY \\ KELLY T. MCKEE and OSCAR SWINEFORD, JR. \\ From the Allergy-Arthritis Division, Department of Internal Medicine, \\ University of Virginia Medical School, Charlottesville, Va., U.S.A.
}

Atrophic arthritis has been produced experimentally in animals, but not under conditions comparable to those observed in man. Study of the disease has thus been handicapped. Homologous tissues plus adjuvants have been used successfully to produce organ-specific lesions in the kidneys (Klinge and Knepper, 1935; Schwentker and Comploier, 1939; Cavelti and Cavelti, 1945a, b, c; Sprunt and others, 1950); in the central nervous system (Kopeloff and Kopeloff, 1944; Kabat and others, 1947; Morgan, 1947); in the heart, skeletal muscle, and connective tissues (Cavelti, 1945; 1947). This paper summarizes unsuccessful attempts in 1946-48:

(1) to produce arthritis in guinea-pigs and rats by injecting homologous joint tissues plus haemolytic streptococci;

(2) to repeat the production of renal lesions by injecting homologous kidney tissues plus haemolytic streptococci (Cavelti and Cavelti, 1945a, b, c; Cavelti, 1945; 1947).

These unsuccessful experiments are reported now because others (Peck and Thomas, 1948; Humphrey, 1948) have been unable to confirm the report of renal lesions by similar methods.

\section{Method}

Guinea-pigs, 400-500 g., were used in the first experiment because they are so susceptible to anaphylactic sensitization. Rats, 200-300 mg., were used in a second experiment, because they had been used successfully by Cavelti and Cavelti.

Antigens were prepared essentially as described by Cavelti and Cavelti (1945a, b, c). Joint tissues and kidneys were removed, aseptically, from anaesthetized animals which had been perfused with saline to remove the blood. Each type of tissue was emulsified in about 6 vols saline in a Waring blender. Four parts of each tissue emulsion, proved sterile by culture, were mixed with one part of a 4 per cent. saline suspension of washed, heat-killed virulent $\beta$ haemolytic streptococci. All mixtures were kept frozen at $-4^{\circ} \mathrm{C}$. until the time of injection.

Twenty-four guinea-pigs were injected every other day for nine doses. The doses were $0 \cdot 1,0 \cdot 2,0 \cdot 4,0 \cdot 6,0 \cdot 8,1 \cdot 0,1 \cdot 0,1 \cdot 0$, and $2 \cdot 0 \mathrm{ml}$., a total of $7 \cdot 1 \mathrm{ml}$. Twelve animals were given articular tissue plus streptococci, and twelve were given kidney emulsion plus streptococci.

Seven weeks after the last injection all of the animals remained perfectly well. Eight were re-injected with a total of $4 \cdot 1 \mathrm{ml}$. of the same antigens in three doses in 5 days. There were no detectable immediate or delayed local or general reactions to the second series of injections. Four received kidney plus streptococci, four received joint tissue plus

* These studies were made possible by a grant from Ciba, Summit, N.J., U.S.A. 
streptococci, and these were killed 2 weeks after the last injection. The other sixteen were killed at the same time, 10 weeks after their first and only series of injections.

Twelve rats were injected with a total of $15 \mathrm{ml}$. joint emulsion plus streptococci, and twelve were given the same amount of kidney emulsion plus streptococci. The doses were $2.0 \mathrm{ml}$. daily for 5 days, then $5.0 \mathrm{ml}$. on the 6 th day. The animals were killed 3 weeks after the last injection.

The kidneys, knee joints, and hearts were removed from the guinea-pigs and rats, and immediately preserved in formalin.

Controls included untreated guinea-pigs and rats, and rats given kidney emulsion, joint emulsion, or suspensions of streptococci.

\section{Results}

No anti-kidney or anti-articular precipitins were demonstrated by the J-tube technique (Pearsall and others, 1945). The collodion-particle method was not used, its value being doubtful unless sterile techniques are employed (Swineford and others, 1947).

Frequent urine analyses showed no more than an occasional cell or trace of albumin in the guinea-pigs and rats treated with kidney emulsion plus streptococci.

$X$-ray and physical examinations of the joints of the animals treated with joint emulsion plus streptococci showed no evidence of joint involvement.

Histologic study of the kidneys, joints, and hearts of the experimental guinea-pigs and rats were indistinguishable from those of the controls.

\section{Summary}

The production of pathological changes in the joints and kidneys of guinea-pigs and rats was attempted by injecting homologous tissue emulsions plus streptococci. Neither antibodies, urinary changes, nor histological changes were demonstrated.

\section{REFERENCES}

Cavelti, P. A. (1945). Proc. Soc. exp. Biol., N.Y., 60, 379.

(1947). Arch. Path., 44, 1.

-

$\longrightarrow$ - (1945b). Ibid., 40, 158.

- - (1945c). Ibid., 40, 163.

Humphrey, J. H. (1948). J. Path. Bact., 60, 211.

Kabat, E. A., Wolf, A., and Bezer, A. E. (1947). J. exp. Med., 85, 117.

Klinge, F., and Knepper, R. (1935). Verh. dtsch. path. Ges., 28, 181.

Kopeloff, L. M., and Kopeloff, N. (1944). J. Immunol., 48, 297.

Morgan, I. M. (1947). J. exp. Med., 85, 131.

Pearsall, H. R., Eversole, S. L., and Swineford, O., Jr. (1945). J. Lab. clin. Med., 30, 548.

Peck, J. L., and Thomas, L. (1948). Proc. Soc. exp. Biol., N. Y., 69, 451.

Schwentker, F. F., and Comploier, F. C. (1939). J. exp. Med., 70, 223.

Sprunt, D. H., Rogers, W. R., and Dulaney, A. D. (1950). Fed. Proc., 9, 344.

Swineford, O., Jr., Houlihan, R., and Robinson, M. B. (1947). J. Allergy, 18, 190.

\section{Sensibilisation par Tissus Homologues}

Tentatives infructueuses de produire des lésions rénales et articulaires ou des précipitines par injections des tissus homologues avec des streptocoques

RÉSUMÉ

L'injection des émulsions des tissus homologues avec des streptocoques aux cobayes et aux rats n'a pas produit de modifications pathologiques dans les articulations ni dans les reins. Ni des anticorps, ni des modifications urinaires ou histologiques ne furent décelés.

Sensibilización por Tejidos Homólogos

Tentativas infructuosas de producir lesiones renales $\mathbf{y}$ articulares o precipitinas mediante inyecciones de tejidos homólogos con estreptococos

RESUMEN

Inyección de emulsiones de tejidos homólogos con estreptococos a cobayos y ratas no llegó a producir alteraciones patológicas de las articulaciones ni de los riñones. Anticuerpos, modificaciones urinarias o alteraciones histológicas no fueron encontrados. 